\title{
Metode Step-by-Step: Apakah dapat meningkatkan hasil belajar lompat jangkit?
}

\section{Step-by-Step Method: Can it improve triple jump learning outcomes?}

\author{
Arifin $^{1}$, Y. Touvan Juni Samodra*1, Edi Purnomo1 \\ ${ }^{1}$ Program Studi Pendidikan Kepelatihan Olahraga Fakultas dan Ilmu Pendidikan \\ Universitas Tanjungpura, Pontianak, Indonesia \\ *Corresponding Author
}

\begin{abstract}
Abstrak
Tujuan dari penelitian ini untuk mengetahui berapa kali peserta didik bisa melakukan gerak lompat jangkit. Penelitian ini merupakan penelitian tindakan kelas. Subjek dalam penelitian adalah peserta didik kelas X SMAN 1 Pulau Maya dengan jumlah 16 peserta didik. Instrumen yang digunakan adalah tes lompat jangkit. Teknik analisis data yang digunakan dalam penelitian adalah deskriptif kuantitatif. Berdasarkan hasil dari penelitian yaitu tes awal, dengan rata-rata sebesar 51,56 yang tuntas hanya satu peserta didik dengan nilai $6,25 \%$. Siklus pertama dengan rata-rata 66,66 terdapat sembilan peserta didik yang tuntas dengan nilai 56,25\%. Namun hasil rata-rata dari tes awal dan siklus Pertama belum mencapai target yang diharapkan. Sehingga dilanjutkan siklus kedua dengan peningkatan rata-rata 72,22 terdapat 11 siswa yang tuntas dengan nilai $68,75 \%$. Sehingga pembelajaran step by step berhasil dari satu peserta didik yang tuntas dengan nilai $6,25 \%$ menjadi $68,75 \%$. Berdasarkan hasil penelitian maka dapat disimpulkan bahwa peningkatan hasil lompat jangkit melalui pembelajaran step by step dapat dilihat dari hasil rata-rata dan ketuntasan setiap peserta didik.
\end{abstract}

Kata Kunci: Step-by-Step; Lompat Jangkit; Pembelajaran.

\begin{abstract}
The purpose of this study was to find out how many times students could do triple jumps. This research is classroom action research. The subjects in the study were students of class X SMAN 1 Maya Island, with a total of 16 students. The instrument used was the triple jump test. The data analysis technique used in this study was descriptive quantitative. Learning through the step-by-step triple jump is dynamic and fun so that students are active in observing every movement in the triple jump. Based on the research results, namely the initial test, with an average of 51.56 who completed only one student with a score of $6.25 \%$. First cycle, with an average of 66.66 , nine students completed with a value of $56.25 \%$. However, the average results from the initial test and first cycle have not reached the expected target. So, it was continued in the second cycle with an average increase of 72.22; 11 students completed with a score of $68.75 \%$. So that the step-by-step learning is successful from 1 student who completes with a score of $6.25 \%$ to $68.75 \%$, based on the results of the study, it can be concluded that the increase in triple jump results through step-by-step learning can be seen from the average and completeness results of each student.
\end{abstract}

Keywords: Step by Step; Triple Jump; Learning.

Received: 17 February 2022; Revised: 19 February 2022; Accepted: 21 February 2022 
Corresponding Author: Y. Touvan Juni Samodra. J1. Ahmad Yani, Pontianak, Kalimantan Barat, 78122

Email: tovan@fkip.untan.ac.id

\section{PENDAHULUAN}

Olahraga atletik ialah merupakan cabang olahraga yang tertua di dunia. yang menjadi induk dari semua cabang olahraga, oleh karna itu Cabang olahraga ini mendapat julukan sebagai Mother of The Sport (Sugarwanto \& Okilanda, 2020). Hal ini dikarenakan olahraga atletik juga merupakan bagian dari olahraga yang terdiri dari beberapa gerakan yaitu, berlari, melompat, dan melempar, salah satunya olahraga lompat jangkit. Sugarwanto \& Okilanda (2020) mengatakan bahwa lompat jangkit disebut juga sebagai lompat tiga yang terdapat dalam gerakan berlari, melangkah dan melompat. Dikdik (2014) mengatakan olahraga lompat jangkit memiliki beberapa gerak yaitu, awalan, jingkat, langkah, dan lompat yang disebut sebagai tolakan, melayang udara serta mendarat. Dapat disimpulkan bahwa olahraga atletik merupakan olahraga tertua yang mendasari beberapa gerak. Lari, jalan, lompat, dan lempar (Febrianti, 2013).

Olahraga atletik merupakan induk dari semua cabang olahraga yang terdapat beberapa cabang dalam olahraga atletik yang diperlombakan lebih dari satu, adapun olahraga yang sering di pertandingkan di even-even, seperti olahraga lari, jalan, lompat dan lempar (Purnomo \& Dapan, 2017). (Susanti et al., 2021)Damrah et al. (2021) olahraga atletik juga merupakan olahraga yang di pertandingkan baik di daerah, kabupaten, kota, provinsi, nasional, bahkan internasional adapun olahraga yang di perlombakan seperti olahraga jalan, lari, lompat, dan lempar, Salah satunya olahraga lompat jangkit. Dapat disimpulkan bahwa olahraga atletik diikut sertakan dalam pertandingan di tingkat daerah bahkan internasional.

(Prasetya \& Maksum, 2013) menyatakan bahwa pembelajaran lompat jangkit sudah ada di dalam kurikulum yang sebenarnya diajarkan di SMA dan SMK. Pendapat lain juga mengatakan bahwa olahraga atletik salah satunya lompat jangkit juga termasuk pembelajaran yang ada dalam 
kurikulum yang di ajarkan dari SD, SMP, dan SMA( Purba, 2014). Hal ini terbukti bahwa pembelajaran lompat jangkit ada dalam kurikulum. Maka perlu seorang guru menerapkan pembelajaran lompat jangkit di sekolah, dari Sekolah Dasar (SD) sampai Sekolah Menengah Atas (SMA), supaya siswa bisa mengenal olahraga atletik salah satunya lompat jangkit. Padahal olahraga lompat jangkit dipertandingkan di tingkat Olimpiade Olahraga Siswa Nasional (O2SN) (Budiarto, 2011). Pendapat sebelumnya juga mengatakan Lompat jangkit juga diikut sertakan dalam perlombaan baik tingkat daerah, kota, provinsi, nasional bahkan internasional seperti Olimpiade yang diselenggarakan oleh PASSI (Purnama, 2017).

Jika lompat jangkit tidak diberikan pembelajaran di sekolah, bagaimana seorang guru memilih bibit atlet yang baru. Lompat jangkit sangatlah penting diterapkan di sekolah sebagai pembinaan dan pembibitan di kalangan sekolah bukan hanya di kalangan mahasiswa (Kresnapati, 2019). Lompat jangkit tidak begitu sulit untuk di lakukan hanya saja butuh tahapan belajar yang bisa membuat siswa melakukan gerak dasar lompat jangkit dengan benar. Ada beberapa penelitian mengatakan bahwa permainan tradisional, latihan plyometric, panjang tungkai, dan latihan lompat kijang bisa meningkatkan hasil lompat jangkit (Agusman, 2016; Kresnapati, 2019; Santosa, 2019; Sobarna et al., 2019).

Masalah yang ada di sekolah bukanlah cara untuk meningkatkan kemampuan lompat jangkit, tetapi memberi pembelajaran bagaimana siswa bisa melakukan gerak dalam lompat jangkit yaitu dengan menggunakan tahapan belajar. (Blegur \& Lumba, 2019) Pembelajaran pendidikan jasmani dilakukan dari bagian-bagian yang mudah ke yang sulit sehingga siswa akan mudah memahaminya. Puspita (2013) bahwa latihan bertahap dapat dengan mudah melakukan gerak dasar latihan. Peneliti sebelumnya juga mengatakan bahwa latihan lompat dengan satu kaki dapat meningkatkan kemampuan lompat jangkit (Sugarwanto \& Okilanda, 2020). Dan diperkuat bahwa dengan latihan bertahap lebih mempermudah gerak (Annas, 2014). Begitu juga sebelumnya mengatakan bahwa latihan dengan "step by step" 
mempermudah dalam suatu teknik gerak yang di ajarkan (Indra \& Marheni, 2020).

Kenyataannya kemampuan siswa saat praktik di lapangan tidak sama dalam melakukan pembelajaran di kelas, salah satunya gerak dalam olahraga lompat jangkit yang diberikan kepada Kelas 10 SMA 1 Pulau Maya Kecamatan Kabupaten Kayong Utara. Sehingga hasil pembelajaran lompat jangkit saat praktik di lapangan belum mencapai Kriteria Ketuntasan Minimum (KKM) yaitu 70, dengan jumlah peserta didik yang tuntas adalah satu (1) peserta didik (6,25\%) dan jumlah peserta didik yang tidak tuntas adalah 15 peserta didik (93,75\%). Hal ini menunjukkan bahwa pembelajaran lompat jangkit mengalami masalah yang harus dicari dalam melakukan pembelajaran lompat jangkit saat di lapangan. Permasalahan yang di hadapi oleh guru penjas dalam menyampaikan materi maupun praktik lapangan khususnya lompat jangkit siswa kurang paham saat akan praktik lapang, sehingga peneliti tertarik dengan menggunakan pembelajaran step by step atau bertahap. Permasalahan ini timbul dari hasil pengamatan dan juga dari pengalaman sebelumnya yang sudah terjadi sejak SMP yaitu pada pembelajaran lompat jangkit yang belum diberi pembelajaran di sekolah.

\section{METODE}

Metode yang digunakan dalam penelitian ini yaitu, metode penelitian tindakan kelas (PTK) guna untuk memperbaiki kemampuan belajar gerak dalam lompat jangkit. Adapun penelitian ini bertujuan untuk memperoleh data tentang peningkatan dalam melakukan gerak dasar lompat jangkit dengan melalui model pembelajaran step by step atau bertahap pada peserta didik kelas 10 SMAN 1 Pulau Maya. Adapun subjek dalam PTK yaitu siswa SMAN 1 Pulau Maya yang terdapat 16 peserta didik yang terdiri dari 8 peserta didik laki-laki dan 8 peserta didik putri.

Penelitian ini dilaksanakan dengan dua siklus dalam melaksanakan penelitian ini mengambil lokasi di SMAN 1 Pulau Maya, yang beralamat Jalan Pendidikan, Desa Dusun Besar, Kecamatan Pulau Maya, Kabupaten Kayong Utara. Pada siswa kelas 10 semester satu tahun ajaran 2021/2022. 
Adapun prosedur dalam penelitian PTK terdiri dari empat rangkaian yaitu, (a) perencanaan, (b) tindakan, (c) observasi, (d) refleksi (Maksum, 2018).

\section{HASIL}

Pra Tindakan dilakukan untuk mengetahui hasil awal dari gerakan lompat jangki yang dilaksanakan di SMAN 1 Pulau Maya dengan 16 siswa pada tabel 1. sebelum melakukan penelitian tindakan kelas pada siklus 1 peneliti mempersiapkan rencana pembelajaran untuk melakukan penelitian di siklus 1 kemudian peneliti mempersiapkan alat pembelajaran berupa peluit, stopwatch, umbul-umbul, tali, tongkat, dan lembar penilaian. Adapun hasil yang diperoleh pada pra tindakan dapat dilihat dalam tabel.

Tabel 2. Rerata perbandingan persentase ketercapaian KKM

\begin{tabular}{lcccrcr}
\hline & Pra Siklus & \multicolumn{2}{c}{ Siklus 1 } & \multicolumn{2}{c}{ Siklus II } \\
\hline Tuntas & 1 & $6,25 \%$ & 9 & $56,25 \%$ & 11 & $68,75 \%$ \\
Belum Tuntas & 15 & $93,75 \%$ & 7 & $43,75 \%$ & 5 & $31,25 \%$ \\
\hline
\end{tabular}

Berdasarkan dari hasil tes awal (pratindakan) dengan prolehan nilai rata-rata peserta didik sebesar 51,56. Dengan jumlah peserta didik yang mencapai KKM hanya satu peserta didik $(6,25 \%)$ dan peserta didik yang belum mencapai kriteria KKM sebanyak 15 peserta didik (93,75\%). Dari pratindakan tes awal ini diketahui bahwa masih banyak peserta didik yang tidak dapat melakukan lompat jangkit dengan benar. Beberapa peserta didik masih banyak yang mengalami kesulitan dalam melakukan gerak jingkat, langkah, dan lompat sehingga nilai tidak mencukupi KKM. Berdasarkan dari data awal yang didapat, peneliti bermaksud untuk memperbaiki dan meningkatkan kemampuan peserta didik dalam melakukan lompat jangkit dengan melalui hasil belajar step by step atau tahapan dalam pembelajaran yang sudah disiapkan oleh peneliti.

Berdasarkan hasil dari tes siklus pertama, peneliti memasuki pembelajaran yang sudah dipersiapkan untuk melakukan pembelajaran disiklus pertama tetapi hasil dari tes awal ke siklus Pertama masih belum mencapai keinginan yang di harapkan sebelumnya. Data yang dimiliki dari hasil tes lompat jangkit pada siklus pertama dengan jumlah nilai keseluruhan 1066,66 dan nilai persentase ketuntasan adalah 56,25\% yang terdapat 9 peserta didik yang tuntas. Berdasarkan hasil data pengamatan 
yang ditemukan dalam kekurangan dan kelebihan yang di temukan pada pembelajaran di siklus pertama sehingga perlu dilanjutkan perencanaan pada tindakan selanjutnya, yaitu pada siklus kedua.

Berdasarkan hasil dari penelitian ada beberapa hal yang di temukan baik dari pertemuan pertama dan kedua dalam siklus kedua antara lain siswa lebih semangat dalam mengikuti pembelajaran pada siklus kedua dan aktif dalam kegiatan sehingga di setiap siklus mengalami peningkatan dan akhirnya pembelajaran di siklus kedua mengalami peningkatan dan peserta didik yang tuntas sudah mencapai $68,75 \%$, berdasarkan hasil perolehan siklus 2 maka pemberian tindakan ini di akhiri sampai dengan siklus kedua. Penjelasan lengkap tampak pada gambar di bawah ini.



Gambar 1. Grafik hasil penelitian

\section{PEMBAHASAN}

Pada tes awal dilakukan tes lompat jangkit sehingga dapat diketahui bahwa tes awal dapat dilihat dari hasil percobaan yang dilakukan siswa, dan ternyata masih banyak siswa yang belum mengerti saat melakukan gerak lompat jangkit. Sehingga diberi pembelajaran lompat jangkit pada siklus 1 yang sesuai dengan RPP dan ternyata dapat dilihat dari hasil bahwa ada peningkatan walaupun masih ada beberapa siswa yang ragu dalam 
melakukan gerakan lompat jangkit. Supaya bisa mencapai KKM yang diharapkan maka dilanjutkan pada siklus 2 dan ternyata setelah diberi perlakukan pada siklus 2 siswa mengalami peningkatan yang di harapkan dengan ketuntasan yang mencapai 68,75\% dengan 11 siswa yang tuntas, dan terdiri dari 16 siswa.

Adapun pembahasan tersebut dapat diketahui melalui hasil tes awal, siklus 1, dan siklus 2 dengan berdasarkan penelitian (Prayoga, 2012) bahwa setelah dilakukan penelitian tindakan kelas diperoleh data yang sudah di ambil dengan melakukan tes lompat jangkit di lapangan. Sedangkan (Warsiyanti, 2019) bahwa di lapangan ternyata siswa belum pernah melakukan tes lompat jangkit. sehingga pembelajaran siswa pada pra tindakan atau tes awal siswa belum mengerti cara bagaimana dalam melakukan gerak lompat jangkit yang benar, setelah di penjelasan mengenai pembelajaran lompat jangkit ternyata siswa sama sekali belum pernah melakukan pembelajaran lompat jangkit sehingga siswa kurang mengerti saat melakukan gerak lompat jangkit.

Warsiyanti (2019) untuk memiliki hasil perlu ada tes yang dilakukan di siklus 1 dan disiklus 2 adapun tes yang dilakukan, yaitu tes lompat jangkit. Sedangkan menurut (Gelen, 2018) bahwa untuk melakukan tes lompat jangkit perlu tahapan belajar. Adapun tahapan yang di berikan latihan gerak yang dilakukan dari mudah kesulitan sehingga penelitian lain juga mengatakan bahwa dengan menggunakan latihan step by step ini bisa dengan mudah melakukan pembelajaran dengan tahapan (Indra \& Marheni, 2020). Sehingga dengan latihan seperti ini akan memudahkan siswa melakukan gerak lompat jangkit. Adapun latihan yang diberikan dalam tahapan belajar menurut (Warsiyanti, 2019) dengan menggunakan sebuah permainan seperti melakukan gerak melompati ban bekas maupun lompat tali untuk melakukan tahapan dalam melompat. Muhendri (2013) juga mengatakan bahwa dengan melalui alat bantu juga meningkatkan pembelajaran lompat jangkit. dan di perkuat pendapat lain bahwa dengan pendekatan bermain engklek juga mempermudah dan meningkatkan hasil pencapaian dalam pembelajaran lompat jangkit (Amirudin, 2019). Berdasarkan pembahasan yang terdapat di pelaksanaan pembelajaran pada 
pra tindakan, siklus I, dan siklus II bahwa di setiap pembelajaran mengalami peningkatan dengan dilihatnya setiap rata-rata yang diperoleh.

\section{KESIMPULAN}

Berdasarkan dari penelitian dapat disimpulkan bahwa dengan peningkatan hasil penelitian lompat jangkit melalui hasil belajar step by step ditandai dengan peningkatan dari setiap nilai rata-rata siswa setiap siklus. Pembelajaran lompat jangkit dengan pendekatan ini ternyata efektif cukup dua kali pertemuan siswa sudah dapat melakukan. Berdasarkan pada hasil penelitian ini maka melihat materi lompat jangkit ternyata mudah, dalam dua kali pembelajaran peserta didik telah mampu menguasai. Cara termudah untuk pembelajaran nomor lompat jangkit adalah dengan penggunaan step by step.

\section{KONTRIBUSI PENULIS}

Penulis 1: Writing - Review \& Editing - Original Draft; Penulis 2: Methodology; Penulis 3: Software and Writing - Validating.

\section{UCAPAN TERIMA KASIH}

Ucapan terima kasih bisa disampaikan kepada pihak sekolah dan siswa SMAN 1 Pulau Maya, Desa Dusun Besar, Kecamatan Pulau Maya, yang telah bersedia dijadikan tempat dan berpartisipasi dalam penelitian.

\section{DAFTAR PUSTAKA}

Agusman. (2016). Hubungan panjang tungkai terhadap hasil lompat jangkit siswa sekolah menengah atas. Jurnal Pendidikan Sosial, Sains Dan $\begin{array}{lrr}\text { Humaniora } & \text { (SG-JPSSH), 2(3), } \\ \text { https://doi.org/ 10.24014/suaraguru.v2i3.2659 }\end{array}$

217-220.

Amirudin, A. (2019). Peningkatan Hasil Belajar Lompat Jauh Melalui Pendekatan Bermain. Multilateral Jurnal Pendidikan Jasmani Dan Olahraga, 17(2), 1-10. https://doi.org/10.20527/multilateral.v17i2.5711

Annas, M. (2014). Pengaruh Latihan Smes Kedeng Menggunakan Area Bertahap Terhadap Keterampilan Smes Sepaktakraw. Journal of Physical Education Health and Sport, 1(1), 35-40. https://doi.org/10.15294/jpehs.v1i1.3010

Blegur, J., \& Lumba, A. J. F. (2019). Improving Teaching Skills of the Prospective Physical Education Teachers through Drill Guide Method. 
Jurnal Pendidikan Jasmani Dan Olahraga, 4(2), 178-188. https://doi.org/10.17509/jpjo.v4i2.19171

Budiarto, P. (2011). Perbedaan Pengaruh Metode Pembelajaran dan Kecepatan Lari terhadap Peningkatan Hasil Belajar Lompat Jangkit (Study Eksperimen Pengaruh Metode Pembelajaran Kompetisi dan Drill pada Peserta Didik Putra SMA Negeri 1 Dagangan Kabupaten Madiun Propinsi Jawa. UNS (Sebelas Maret University).

Damrah, Pitnawati, P., Fitri, J. N., Erianti, \& Astuti, Y. (2021). Evaluasi pelaksanaan pemusatan latihan atletik. Altius: Jurnal Ilmu Olahraga Dan Kesehatan, $10(1)$, https://doi.org/10.36706/altius.v10i1.12887

126-142.

Dikdik, Z. S. (2014). Mengajar dan Melatih Atletik. Bandung: PT Remaja Rosdakarya, 18-19.

Febrianti, R. (2013). Pengembangan Materi Atletik Melalui Permainan Atletik Three in One Untuk Siswa Sd Kelas V. Journal of Physical Education And Sports, 2(1). https://doi.org/10.15294/jpes.v2i1.1272

Gelen. (2018). Pengaruh Latihan Split Squat Jump Terhadap Hasil Lompat Jangkit pada Kegiatan Ekstrakurikuler SMK Negeri 2 Palembang Tahun ajaran 2017/2018.

Indra, P., \& Marheni, E. (2020). Pengaruh Metode Latihan dan Motivasi Berlatih terhadap Keterampilan Bermain Sepak Bola Ssb Persika Jaya Sikabau. Jurnal Performa Olahraga, 5(1), 39-47. https://doi.org/10.24036/jpo138019

Kresnapati, P. (2019). Pengaruh Pola Latihan Lompat Kijang Terhadap Hasil Lompat Jangkit Mahasiswa Putra Pjkr Upgris. Journal of Sport Coaching and Physical Education, 3(1), 9-15. https://doi.org/10.15294/jscpe.v3i1.31883

Maksum, A. (2018). Metodologi Penelitian dalam Olahraga. Unesa University Press.

Muhendri, I. (2013). Peningkatan Hasil Belajar Lompat Jangkit Melalui Alat Bantu Pembelajaran Pada Siswa Kelas Xii Ipa 2 Sma Negeri 1 Teras Kabupaten Boyolali Tahun Ajaran 2012/2013. Phederal: Physical Education, Health and Recreation Journal, 1(1).

Prasetya, R. R., \& Maksum, A. (2013). Hubungan Antara Kekuatan Otot Tungkai Dengan Hasil Belajar Lompat Jangkit Siswa SMAN 1 Taman. Jurnal Pendidikan Olahraga Dan Kesehatan, 1(1), 55-59.

Prayoga, aba sandi. (2012). Upaya Peningkatan Kemampuan Lompat Jangkit Melalui Pembelajaran Menggunakan Alat Bantu Mahasiswa Penkepor JPOK FKIP UNS Angkatan 2011.

Purnama, S. (2017). Pengaruh Manajemen Fasilitas Olahraga Dan Layanan Guru Terhadap Efektivitas Pendidikan Jasmani Olahraga Dan Kesehatan. Journal Sport Area, 2(2), 105-114. https://doi.org/10.25299/sportarea.2017.vol2(2).704

Purnomo, E., \& Dapan. (2017). Dasar-Dasar Gerak Atletik. Yogyakarta: 
Alfamedia, 26-28.

Puspita, E. (2013). Perbedaan pengaruh latihan tolak peluru dengan beban tetap dan beban bertahap terhadap kemampuan tolak peluru gaya orthodox pada siswa putra kelas xi ipa sma negeri 1 ceper tahun ajaran 2012/2013.

Santosa, A. (2019). Pengaruh Permainan Tradisional Terhadap Hasil Belajar Lompat Jangkit. Jpoe, 1(2), 98-105. https://doi.org/10.37742/jpoe.v1i2.39

Sobarna, A., Hambali, S., Rizal, R. M., \& Sevtiadzi, L. (2019). HASIL KETERAMPILAN LOMPAT JANGKIT (Studi Eksperimen Menggunakan Latihan Plyometrik). Jurnal Pendidikan Olahraga, 8(1), 53. https://doi.org/10.31571/jpo.v8i1.1233

Sugarwanto, S., \& Okilanda, A. (2020). Pengaruh Latihan Single Leg Hops Terhadap Hasil Lompat Jangkit Siswa Smp 1 Sungai Lilin. Kinestetik, 4(1), 85-89. https://doi.org/10.33369/jk.v4i1.10472

Susanti, E., Syafaruddin, \& Victorian, A. R. (2021). Survei Sarana Dan Prasarana Penjaskes Di Smp Se-Kecamatan Lalan, Musi Banyuasin. Jurnal Kejaora (Kesehatan Jasmani Dan Olah Raga), 6(2), 212-219. https://doi.org/10.36526/kejaora.v6i2.1357

Warsiyanti, Y. (2019). Upaya Peningkatan Hasil Belajar Lompat Jauh Melalui Pendekatan Bermain Lompat Tali pada Siswa Kelas IV Sekolah Dasar. JPI (Jurnal Pendidikan Indonesia): Jurnal Ilmiah Pendidikan, 5(1). https://doi.org/10.20961/jpi.v5i1.33838 